\title{
Effect of Chimato Composts Made Using Optimal Blending Composition of $T$. diversifolia on Fertilizer Requirements and Maize Yield
}

\author{
Angstone Thembachako Noel J. Mlangeni ${ }^{1}$, Sosten Staphael Chiotha ${ }^{3}$, Elijah Aureliano Kamundi ${ }^{1}$ \\ \& Shaibu Kananji ${ }^{2}$
}

${ }^{1}$ Natural Resources Department, Natural Resources College (of Malawi), Lilongwe University of Agriculture and Natural Resources, Lilongwe, Malawi

${ }^{2}$ Agriculture Department, Natural Resources College (of Malawi), Lilongwe University of Agriculture and Natural Resources, Lilongwe, Malawi

${ }^{3}$ Biology Department, University of Malawi, Malawi

Correspondence: Angstone Thembachako Noel J. Mlangeni, Natural Resources Department, Natural Resources College (of Malawi), Lilongwe University of Agriculture and Natural Resources, Lilongwe, Malawi. E-mail: anjtmlangeni@gmail.com

Received: April 8, 2014 Accepted: May 5, 2014 Online Published: November 15, 2014

doi:10.5539/jas.v6n12p185 URL: http://dx.doi.org/10.5539/jas.v6n12p185

\begin{abstract}
A field experiment was conducted to determine amount of inorganic fertilizer saved by using chimato composts TD60 produced by blending $60 \%$ of Tithonia diversifolia with $40 \%$ maize stalks in maize production. In this experiment, $0 \mathrm{~g}, 100 \mathrm{~g}, 200 \mathrm{~g}$ and $400 \mathrm{~g}$ of TD60 were supplied per maize planting station in combination with $0 \%, 33 \%, 67 \%$ and $100 \%$ of recommended rates of NPK $(23-21-0+4 \mathrm{~S})$ inorganic fertilizer. Maize growth parameters and yield were measured. Results showed that maize cob length, cob circumference, leaf length and maize grain mass in treatment supplemented with $200 \mathrm{~g}$ of TD60 combined with $33 \%$ of NPK were significantly different from those supplemented with lower quantities of chimato composts and were not significantly different from those supplemented with TD400 combined with 23-21-0+4S quantities of equal to or greater than $33 \%$ of the recommended rates. However, maize cob length and cob circumference were not significantly different in maize plants supplemented with $400 \mathrm{~g}$ and $200 \mathrm{~g}$ of TD60. Yield of maize were maximal in planting stations supplemented with $200 \mathrm{~g}$ and $400 \mathrm{~g}$ of TD60 combined with $67 \%$ and $33 \%$ of recommended rates of NPK respectively. It is concluded that application of $200 \mathrm{~g}$ and $400 \mathrm{~g}$ of TD60 combined with $67 \%$ and $33 \%$ of recommended rate of NPK respectively are likely to produce optimal growth parameters as well as optimal maize yield if recommended to smallholder farmers.
\end{abstract}

\section{Introduction}

Soil fertility degradation has been ranked as one the most critical problems affecting agricultural development in Sub-Saharan Africa including Malawi and has serious consequences and implications on economic development and food security respectively (Stoddard, 2005; Gachengo et al., 1999; Tchale, 2006). Diminishing soil fertility is failing to support increased crop production and is thereby affecting Malawi's agricultural development and critically limiting food security in most Sub Saharan countries including Malawi (Kiptot, 2008; Tchale, 2006) such that most smallholder gardens produce far much below the potential yield (Murugan \& Swarnam, 2013). Recent reports indicate that yield of local maize varieties grown in witch-weed prone and poor soils fields without inorganic chemical fertilizers application has diminished from $1700 \mathrm{~kg} / \mathrm{ha}$ (yielded) in the $1960 \mathrm{~s}$ to less than $1000 \mathrm{~kg} / \mathrm{ha}$ in 2000s (MMFS, 2008). Several soil fertility enrichment strategies and technologies have been suggested. Addition of inorganic chemical fertilizers is one of such soil fertility enhancing technologies that have been adopted worldwide. Application of inorganic chemical fertilizers has the advantage of accurately supplying plants with the proper balance of nitrogen, $\mathrm{N}$, phosphorus, $\mathrm{P}$, and potassium, $\mathrm{K}$, hence more cost-effective (Ganunga et al., 1998; Onwueme \& Sinha, 1991; Swift, 1979). However effectiveness of inorganic chemical fertilizers is dependent on application methods and proper crop rotation (Ganunga et al., 1998). Another merit for inorganic fertilizers is that these fertilizers contribute to raising total amount of plant nutrients in the soil even 
though they do not provide organic matter that loosely traps the nutrient in the soils. In the first place, continued use of inorganic fertilizers, without maintaining organic matter content of the soil has lead to loss of topsoil fertility, poor rooting conditions for maize growth, less rainfall infiltration and increased erosion worsening the soil life (Murugan \& Swarnam, 2013). Besides, chemical fertilizers alter soil acidity and alkalinity which negatively impact on certain crop production. Thus, use of inorganic fertilizers has also affected soil $\mathrm{pH}$ by making it more acidic, not favourable to most crops including maize. In addition, inorganic chemical fertilizers are becoming very expensive (MMFS, 2008) especially to poor smallholder households practicing farming in Malawi such they are almost not affordable. Even if inorganic chemical fertilizers were made affordable and available through fertilizer subsidy programmes, $100 \%$ dependence on inorganic chemical fertilizers would not be recommended since crops' response to inorganic chemical fertilizers is reported to be declining (MMFS, 2008) partly because of loss of soil organic matter due lack of soil enrichment programmes other than inorganic chemical fertilizer addition. Over dependence on supplementing soils with inorganic chemical fertilizers has also brought a number of negative effects on soils' capability to produce (MMFS, 2008; Murugan \& Swarnam, 2013). Furthermore, use of inorganic chemical fertilizers has increased smallholder farmers' dependence on inorganic chemical fertilizers themselves for crop production thereby forcing smallholder farmers to ignore other equally important good farming and soil conservation practices such as crop rotation, compost making and use, manure application and others.

In Malawi, smallholder farmers are encouraged to make and use Chimato compost as source of organic matter and plant nutrient such as nitrogen $(\mathrm{N})$, phosphorus $(\mathrm{P})$, potassium $(\mathrm{K})$, calcium $(\mathrm{Ca})$, magnesium $(\mathrm{Mg})$ and others. The merit of use of chimato compost is that it takes shorter period to mature (Mlangeni et al., 2013; MMFS, 2008). Mlangeni et al. (2013) reported that chimato compost made by blending $60 \%$ of Tithonia diversifolia ( $T$. diversifolia) with $40 \%$ maize stalks optimizes nitrogen content in compost which is the most limiting nutrient in most soils in Malawi (Stoddard, 2005; Tchale, 2006). Blending of maize stalks with $T$. diversifolia has indicated to significantly improve nitrogen content in resultant compost (Mlangeni \& Chiotha, 2013). For example, chimato compost produced with maize stalks only possess total nitrogen amounting to about $1.17 \%$, whereas chimato compost produced by blending $25 \%, 50 \%$ and $60 \%$ of $T$. diversifolia possess total nitrogen amounting up to $1.37 \%, 2.33 \%$ and $2.47 \%$ respectively (Mlangeni et al., 2013). Efficient use of well matured composts in crop production reduces requirements for purchased inorganic chemical fertilizers. It is therefore imperative to determine cost of inorganic fertilizers saved by using improved chimato composts that is produced by blending $60 \%$ of Tithonia diversifolia with $40 \%$ of maize stalks that possesses large quantities of nitrogen $(2.7 \%)$. the studies was carried out to establish the potential and extent to which chimato compost produced by blending $60 \%$ of Tithonia diversifolia with $40 \%$ of maize stalks reduce smallholder farmers' inorganic chemical fertilizer requirements as well as potential of improving vegetative growth and yield of maize crop thereby determining equivalent amounts and costs of inorganic fertilizer saved increasing crop production in fields with poor soil fertility.

\section{Materials and Methods}

\subsection{Study Site}

The study was carried out within Group village headman Mdzoole's area, Ming'ongo Extension Planning Area, in Lilongwe District, Malawi. Mdzoole village is about $36.5 \mathrm{~km}$ west of Lilongwe town and lies at an altitude of $1147 \mathrm{~m}$ above sea level experiences a mean annual temperature of $20^{\circ} \mathrm{C}$, a mean annual relative humidity of 68 $\%$ and receives an annual mean rainfall of $892 \mathrm{~mm}$ of which $85 \%$ falls between November and March (DARETS, 2012). The selected field possessed sandy loam soils low soil carbon content, low soil nitrogen content, low $\mathrm{C} / \mathrm{N}$ ratio and acidic soil $\mathrm{pH}$ of approximately $3.5 \%, 0.45 \%, 6.4: 1$ and 6.2 respectively.

\subsection{Experimental Design and Treatments.}

A smallholder farmers' field with known symptoms of poor soil fertility was identified and initial soil carbon and nitrogen and $\mathrm{pH}$ were measured using the Kjeldahl apparatus (Jeffery et al., 1989) and pH meters. DK 8051 maize seed variety was purchased from Agricultural Trading Company, a leading agrochemical dealer in Malawi. Chimato compost TD50 and TD60 were made by blending 50\% and $60 \%$ of Tithonia diversifolia with $50 \%$ and $40 \%$ of maize stalks respectively in three replicates. One maize seed was planted per planting station at $25 \mathrm{~cm}$ apart. Homogenously mixed chimato compost TD60 was supplemented to maize crop. The compost treatment used a design of $1 \times 4 \times 4$ factorial experiment laid out in a randomized complete block design (RCBD) with three replications where quantities of chimato composts (Td60) per planting station $(0 \mathrm{~g}, 100 \mathrm{~g}, 200 \mathrm{~g}$ and $400 \mathrm{~g})$ were the main plot factors and quantities of NPK: $23: 20: 0+4 \mathrm{~S}$, basal dressing inorganic chemical fertilizers, $(0,33 \%$, $67 \%$ and $100 \%$ of the recommended rates) were the sub plot factor. The sample's initial soil carbon and nitrogen 
were measured using the Kjeldahl apparatus (Jeffery et al., 1989).

\subsection{Data Collection}

Nitrogen content of NPK was calculated from the nominal values of nitrogen indicated on bags of NPK fertilizers. Nitrogen content of chimato compost TD50 and TD60 was obtained from values reported by Mlangeni and others (2013). Maize plant growth parameters (such as leaf length at nod containing a cob, plant height, cob length, cob circumference) and average mass of yield per maize stalk) were measured using calipers.

\subsection{Data Analysis}

The collected data was analyzed using Microsoft office excel and SPSS version 11.5 to develop model of relationships between quantities of chimato compost and inorganic chemical fertilizers requirements and maize growth parameters (cob circumference, cob length, maize plant height) and maize yield. Analysis of various (ANOVA) was used to determine level of variation in cob length, cob circumference, leaf length, plant height and maize yields.

\section{Results and Discussions}

\subsection{Comparison Quantities of Nitrogen in Organic Fertilizers and Chimato Composts}

Table 1. Quantity of Nitrogen in Urea, NPK and chimato composts

\begin{tabular}{|c|c|c|c|c|c|c|c|}
\hline \multicolumn{5}{|c|}{ Chimato compost } & \multicolumn{3}{|c|}{ Inorganic fertilizers } \\
\hline $\begin{array}{l}\text { Compost } \\
\text { Treatment }\end{array}$ & $\begin{array}{l}\text { N supplied } \\
\text { by } 100 \mathrm{~g}(\mathrm{~g})\end{array}$ & $\begin{array}{l}\text { N supplied } \\
\text { by } 200 \mathrm{~g}(\mathrm{~g})\end{array}$ & $\begin{array}{l}\text { N supplied } \\
\text { by } 400 \mathrm{~g}(\mathrm{~g})\end{array}$ & $\begin{array}{c}\mathrm{N} \text { supplied } \\
\text { by } 1000 \mathrm{Kg} \\
\quad \text { in } \mathrm{Kg}\end{array}$ & $\begin{array}{c}\text { Type of } \\
\text { Fertilizers }\end{array}$ & $\begin{array}{l}\mathrm{N} \text { supplied } \\
\text { by } 50 \mathrm{Kg}\end{array}$ & $\begin{array}{l}\mathrm{N} \text { supplied } \\
\text { by } 100 \mathrm{Kg}\end{array}$ \\
\hline $\mathrm{Td} 50$ & 2.33 & 4.66 & 9.32 & 23.30 & UREA & 23.0 & 46.0 \\
\hline Td60 & 2.47 & 4.94 & 9.88 & 24.70 & $23-20-0$ & 11.50 & 23.0 \\
\hline
\end{tabular}

As shown in table 1, 1.0 ton of chimato composts TD50 and TD60 contained nitrogen amounting $23.30 \mathrm{Kg}$ and $24.70 \mathrm{Kg}$ respectively comparable to nitrogen contained in $50 \mathrm{~kg}$ mass and $100 \mathrm{~kg}$ mass of urea and NPK fertilizers respectively. The observation indicates that amounts of nitrogen provided by 1.0 ton of chimato composts $\mathrm{Td} 50$ and 1.0 ton of chimato composts Td60 is approximately equivalent to total nitrogen that one-50 $\mathrm{kg}$ bag of urea (46\%) fertilizers and two-50 kg bags of NPK (23-21-0+4S) provides. Therefore, a smallholder farmer would save at least one bag of Urea or two bags of 23-21-0+4S by supplying 2.0 ton of chimato composts made using $50 \%$ and $60 \%$ of $T$. diversifolia, which is a significant saving. Production of chimato composts by blending $50 \%$ or $60 \%$ of $T$. diversifolia with maize stalks has great potential of supplying crops with large amounts of nitrogen as suggested (Mlangeni \& Chiotha, 2013; Mlangeni et al., 2013). Thus, composting $T$. diversifolia biomass, which is abundant and mostly lie idle along roads, streams and waterways and desolate fields in most parts of Malawi, would produce large quantities of nitrogen rich chimato composts that would probably benefit majority of poor smallholder farmers and cover up for inorganic fertilizers deficits that smallholder farmers usually have after accessing inadequate subsidy inorganic chemical fertilizers. Saving of one bag or more would significantly improve household agribusiness development as well as household food security of poor households that fail to buy inorganic chemical fertilizers if making and use of TD50 or TD60 or both is encouraged among smallholder farmers.

\subsection{Effect of TD60 on Vegetative Growth}

\subsubsection{Cob Circumference and Length}

As shown in Figures 1a and 1b, despite supplementing the maize crop in the control treatments with inorganic chemical fertilizers, it was observed that growth of cob length and cob circumference poorly responded to the chemical fertilizers. The cob length and cob circumference increments were much lower as expected with soils of low fertility quality which fail to support growth of crops (Biddlestone \& Gray, 1987; Chang et al., 2009) and negatively affect crop produce. 


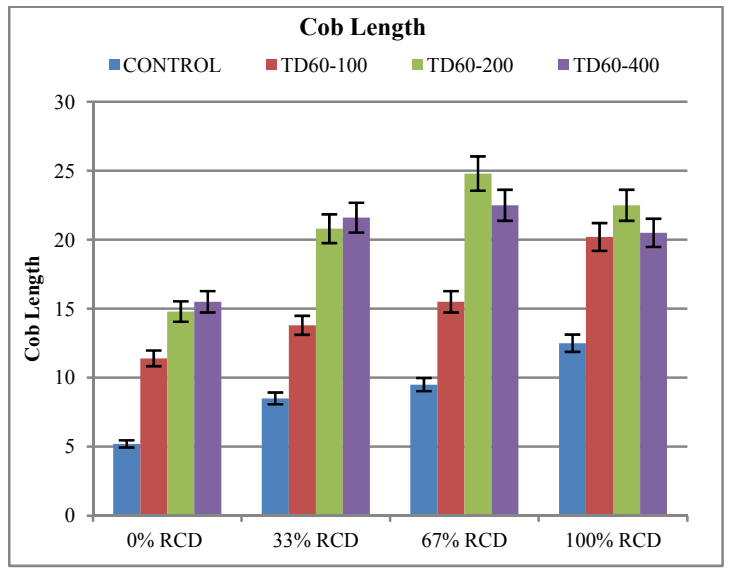

a.

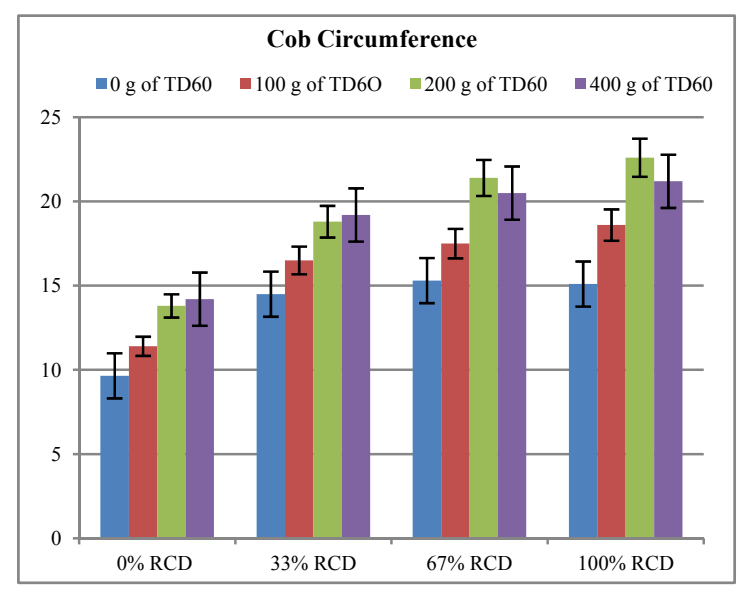

c.

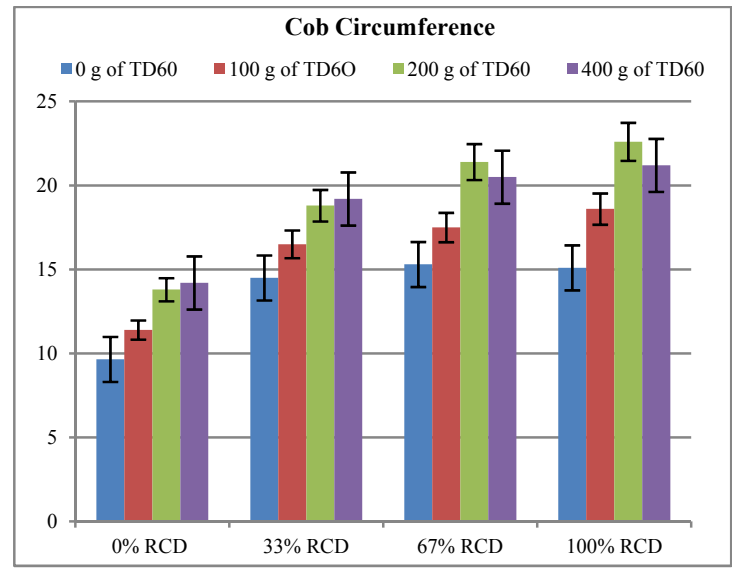

b.

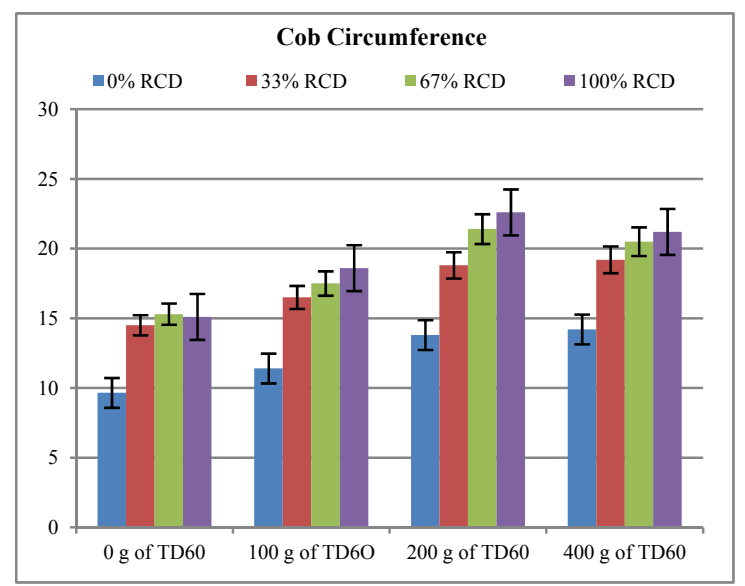

d.

Figure 1. Comparison of maize cob length and cob circumference

The observation confirms that maize growth parameters in maize grown in poor soils with little or no organic matter or grown soils without amendment of high quality composts respond poorly to application of inorganic chemical fertilizer which is line with finding of others (Benson et al., 1997; Chang et al., 2009). In addition, the control treatment produced cobs with shortest length and circumference confirming that soil degradation and nutrients depletion levels have worsened (Tchale, 2006) such that fertilizer application alone could not produce any meaningful yield and benefit to smallholder farmer (Gachengo et al., 1999; Babajide et al., 2008). Application of $33 \%$ of recommended rate of inorganic chemical fertilizers alone in fields with poor soil fertility produced insignificant differences in cob length and cob circumference $(p=0.46 ; \alpha=0.05$; Wilcoxon). The observation is attributed to microbial activities in nitrogen poor environment which have high demand for nitrogen. Addition of inorganic fertilizers alone supplied the soils with nitrogen that met the demand of microorganisms for nitrogen for decomposition depriving the intended maize plants for the same which probably negatively affected the observed plant growth parameter (UNIU, 2014). The observed poor growth parameters in soils supplemented with lower quantities of TD60 could be that there was TD60 supplied lower quantities of nitrogen atoms that primarily served the microorganism's demand for nitrogen as well which also could negatively impacted on plant growth (UNIU, 2014; Mlangeni et al., 2013).

As shown in Figure 1, maize cob length and circumference in maize plants treated with no fertilizer $(0 \%)$, steadily increased with increased dosages of TD60 as follows: cob length in

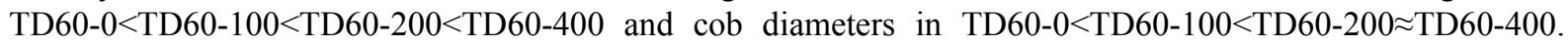
Thus, significant differences in cob circumference and cob length were observed between control and treatment experiments. Cob circumference and cob length of maize plants in treatment supplemented with $0 \mathrm{~g}$ of TD60 were significantly different from those supplemented with $100 \mathrm{~g}, 200 \mathrm{~g}$ and $400 \mathrm{~g}$ of $\mathrm{TD} 60(\mathrm{P}=0.001 ; \alpha=0.05$; 
Wilcoxon). The observation indicates that shortest cob length and cob circumference increased in increasing order of chemical fertilizer content supplied in the control treatments. Similarly, in maize plants supplemented with chimato compost TD60, the shortest cob length was observed in treatment supplemented $100 \mathrm{~g}$ of TD60 and increased in increasing order of quantity of chimato compost TD60. The observation is attributed to increased soil fertility, improved nutrition and nutrient uptake provided by the nutrient rich compost TD60 (Babajide et al., 2008; Mlangeni, 2013). Within the specified quantity of compost TD60, cob length and cob circumference further increased with increased quantities of chemical fertilizer except in treatment supplemented with $400 \mathrm{~g}$ of TD60 in which a decrease was observed. The observation indicates that high dosage of TD60 (400 g) combined with high dosage of chemical fertilizers might have introduced some levels of soil toxicity which negatively affect soil chemistry, microbial activities as well as plant growth (Biddlestone \& Gray, 1987; Chang et al., 2009). It is noted that there is insignificant impact of $67 \%$ of full dosage and greater of chemical fertilizers application on cob length and circumference of maize crop planted in soils supplemented with enormous amounts nitrogen rich composts. Reduced effect on maize growth parameters were observed in maize plants planted in soil with little or no composts. As shown in Figures 1c and 1d, $200 \mathrm{~g}$ of chimato composts of TD60 supplied per planting station positively responded to varied dosages of inorganic chemical fertilizers by producing proportional increments in cob circumference and cob length. The addition of $200 \mathrm{~g}$ of TD60 probably optimally improved the soils' capability of releasing appropriate amounts of nutrients for the crop to use throughout their life cycle. The $200 \mathrm{~g}$ of TD60 also enhanced good soil aeration and improved moisture holding capacity since the crops supplied with $200 \mathrm{~g}$ of TD60 were not affected by the dry spell that was experienced for two weeks.

The observation also indicates that supplementation of $400 \mathrm{~g}$ of chimato composts of TD60-400 per planting station caused moderate increases in cob length and cob circumference as quantities of inorganic fertilizers were increased. However, the increases were not statistically different $(p=0.207 ; \alpha=0.05$; Wilcoxon). Thus no significant increment in cob length and cob diameter was observed by doubling quantity of chimato composts TD60 from $200 \mathrm{~g}$ to $400-\mathrm{g}$. The observation is attributed to large amounts of nitrogen that probably exceeded an optimal limit. Thus $200 \mathrm{~g}$ and $400 \mathrm{~g}$ supplied total nitrogen of about $4.99 \mathrm{~g}(2 \times 2.47=4.99 \mathrm{~g})$ and $9.88 \mathrm{~g}(4 \times 2.47$ $=9.88 \mathrm{~g}$ ) respectively which also increased quantities of available nitrogen in the soil ((Biddlestone \& Gray, 1987; Mlangeni et al., 2013). Addition of inorganic fertilizers at $67 \%$ and $100 \%$ the recommended rate in planting stations supplemented with $400 \mathrm{~g}$ of chimato compost further increased quantities of Nitrogen to levels not favourable for plant growth (Murugan \& Swarnam, 2013; Chang et al., 2009), which specifically affected diffusion of nutrients in the soil. The maize plants that survived in planting stations supplied with TD400 were well established and yielded largest quantity of biomass by mass. Large quantity of TD60 provided enormous nitrogen which might be responsible for the vegetative growth increase (Biddlestone \& Gray, 1987)

\subsubsection{Plant Height and Leaf Length}

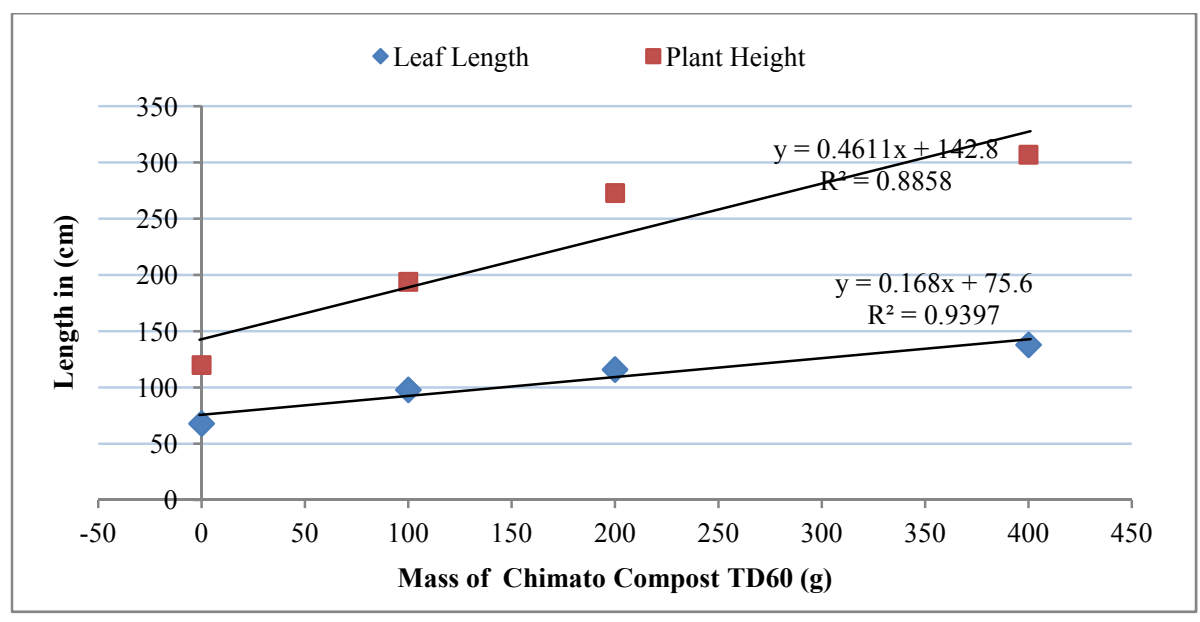

Figure 2. Linear relationships of maize leaf length and plant height

As shown in Figure 2, maize plants height and leaf length in treatment supplemented with $100 \mathrm{~g}, 200 \mathrm{~g}$ and 400 $\mathrm{g}$ of TD60 were generally found more superior than the control experiment with no input of TD60. However, most significant increments/ in maize plant height and leaf length were observed in treatments supplemented 
with $400 \mathrm{~g}$ then $200 \mathrm{~g}$ followed by $100 \mathrm{~g}$ of TD60. Effects of chimato compost TD60 on plant height and leaf length were clearly shown in treatments supplemented $100 \mathrm{~g}, 200 \mathrm{~g}$ and $400 \mathrm{~g}$ of TD60 in which plant height increased up to $194 \mathrm{~cm}, 273 \mathrm{~cm}$ and $307 \mathrm{~cm}$ respectively which were $62 \%, 128 \%$ and $156 \%$ higher than the control of no TD60 input treatment (0 g of TD60). Similarly, their leaf length increased up to $98 \mathrm{~cm}, 116$ and 138 $\mathrm{cm}$ respectively representing $44 \%, 71 \%$ and $103 \%$ higher than the control of no TD60 input as well even though they were all supplemented with no inorganic chemical fertilizers ( $0 \mathrm{~g}$ of inorganic chemical fertilizers). The findings indicates that quantities of chimato composts were responsible the observed growth parameters increases - greater quantities of chimato composts TD60 caused maize plants grow more taller and maize leaf grow longer. Thus, increase in quantity of TD60 resulted in proportional increase in plant height and leaf length. Furthermore, a linear model relating quantity of chimato composts TD60 and plant height was developed as follows:

$$
\mathrm{y}=0.461 \mathrm{x}+142.8
$$

Where $y$ is quantity of chimato compost TD60 in grams and $\mathrm{x}$ is length of the plant in $\mathrm{cm}$.

The relationship $\left(r^{2}=0.885\right)$ confirmed that plant height could be attributed to quantity of YD60 in the soil that increased soil plant nutrition and nutrients that the maize crop used for growth. However, the equation gradient was small indicating less increase in plant height is produced by a larger mass of chimato compost TD60.

Further analysis for leaf length resulted in a linear equation:

$$
\mathrm{y}=0.168 \mathrm{x}+75.6
$$

Where $y$ is quantity of chimato compost TD60 in grams and $\mathrm{x}$ is leaf length of the maize plant in $\mathrm{cm}$.

The $r$ value is larger $\left(r^{2}=0.939\right)$ that indicates stronger correlation and the small gradient further indicates that greater increase in quantity small increase in leaf length. Thus, equation 1 and 2 confirmed correlation and direct proportionality of quantity of chimato composts TD60 and maize plant height and leaf length. The finding was in line with findings described in section 3.1 that indicates that chimato composts TD60 possess greater quantities of nitrogen, and other plant nutrients that enhanced the observed greater plant growths.

On the other hand, insignificant differences ( $\mathrm{p}=0.207 ; \alpha=0.05$; Wilcoxon) were observed among control treatments that were treated with $0 \mathrm{~g}$ of TD60 combined with $0 \%, 33 \%$ and $67 \%$ of inorganic chemical fertilizers. The observation indicated that inorganic chemical fertilizers did not enhance significant differences in plant height and leaf length. The findings are in line with reports by MMFS (2013) and Babajide (2008) that chemical fertilizers respond poorly in soils with low organic matter content. However, maize plant height and leaf length in treatment supplemented with $0 \mathrm{~g}$ of TD60 combined with $100 \%$ of the recommended quantities of inorganic chemical fertilizers were significantly different from treatments supplemented with $0 \mathrm{~g}$ of TD60 combined with 0,33 and $67 \%$ of the recommended quantities of inorganic chemical fertilizers. The results indicate that application of inorganic chemical fertilizers in quantities other than the recommended quantities in soils of poor quality without organic manure or compost supplementation fail to enhance or induce significant differences in plant height and leaf length of maize plant. The results established that supplementation of inorganic chemical fertilizers into soils of poor quality supplemented with good quality chimato compost TD60 enhance significant vegetative growth especially plant height and leaf length ( $p=0.005 ; \alpha=0.05$; Wilcoxon). The differences are attributed to organic matter as well as enormous nitrogen supplied by the chimato compost TD60 (Mlangeni et al., 2013; Babajide, 2008) that allow gradual release of available nitrogen and other essential nutrients to the maize plant. In addition, greater quantities TD60 (200 g and $400 \mathrm{~g}$ ) significantly increase soil organic matter that improve soil physical and chemical properties which are associated with improved availabilities and mobility nutrient which in turn affect maize plant growth.

Table 2. Effect of TD60 on leaf length, plant height, and cob length and cob circumference as quantities of TD60 is increased $(0 \mathrm{~g}, 200 \mathrm{~g}, 400 \mathrm{~g} \& 600 \mathrm{~g})$

\begin{tabular}{llll}
\hline Parameter & Equation & R value & Gradient of equation \\
\hline Plant Height & $\mathrm{Y}=64.00 \mathrm{x}+63.5$ & 0.975 & 64.00 \\
Cob Length & $\mathrm{Y}=22.80 \mathrm{x}+48$ & 0.989 & 22.80 \\
Cob Diameter & $\mathrm{Y}=498 \mathrm{x}+9.2$ & 0.812 & 4.98 \\
Leaf Length & $\mathrm{Y}=4.16 \mathrm{x}+4.65$ & 0.985 & 4.20 \\
\hline
\end{tabular}


Further analyses were carried out to assess the combined effects of quantity of chimato TD60 and quantity of inorganic fertilizers (NPK). The results indicate a strong linear correlation between quantities of TD60 and NPK on one hand and maize crop growth parameters (cob length, cob circumference, plant height and leaf length. The mathematical correlation confirms findings stated in sections 3.1 and 3.2. Direct proportional relationships between the combined effect of quantity of TD60 and NPK on cob length, cob circumference, plant height and leaf length were developed (Table 2). Similarly, large $\mathrm{R}^{2}$ values indicate that quantity of chimato composts and fertilizers supplied into the treatments were responsible for the increases observed in plant growth parameters. However, a departure from the models was observed in treatment supplemented with $400 \mathrm{~g}$ of TD60 combined with 33\% chemical fertilizers that produced greatest plant height and leaf length. Leaf length and plant height were observed declining from $90.45 \mathrm{~cm}$ and $225 \mathrm{~cm}$ to $87.25 \mathrm{~cm}$ and $223 \mathrm{~cm}$ in treatment supplemented with TD400 combined with $67 \%$ inorganic chemistry fertilizers. Leaf length and plant height were observed increasing again to 91.05 and $224 \mathrm{~cm} \%$ in treatment supplemented withTD60 combined with $100 \%$ chemical fertilizers. However, plant height and leaf length of these treatments were not significantly different each other ( $p$ $<0.002, a=0.05$, Wilcoxon). The observed slight decrease is attributed to increased saturation of nitrogen which negatively affected plant growth especially at the early stages (Benson et al., 1997; Benson, 1997).

\subsection{Effect of TD60 on Maize Yield}

Table 3. Estimated maize yield per hectare supplemented with varied quantities of TD60 and inorganic chemical Fertilizers

\begin{tabular}{ccccc}
\hline \multirow{2}{*}{ Quantity of chimato compost TD60 $(\mathrm{g})$} & \multicolumn{4}{c}{ Maize Yield } \\
\cline { 2 - 5 } & $0 \% \operatorname{RICF}(\mathrm{Kg})$ & $33 \% \mathrm{RICF}(\mathrm{Kg})$ & $67 \%$ RICF $(\mathrm{Kg})$ & $100 \%$ RICF $(\mathrm{Kg})$ \\
\hline 0 & $1,411.50 \pm 71.50$ & $1,885.50 \pm 94.27$ & $2,125.00 \pm 106.27$ & $2,168.50 \pm 108.40$ \\
100 & $2,101.40 \pm 105.07$ & $4,248.65 \pm 212.40$ & $5,763.05 \pm 288.13$ & $6,589.00 \pm 329.47$ \\
200 & $3,981.50 \pm 199.50$ & $12,667.58 \pm 663.20$ & $13,213.25 \pm 661,66$ & $12,525.25 \pm 626.26$ \\
400 & $9,981.27 \pm 499.00$ & $13,059.00 \pm 653.05$ & $12,811.00 \pm 641.05$ & $12,768.40 \pm 638.50$ \\
\hline
\end{tabular}

Maize yield varied significantly among treatments supplemented with $0 \mathrm{~g}, 100 \mathrm{~g}, 200 \mathrm{~g}$ and $400 \mathrm{~g}$ of TD60 combined with $0 \%, 33 \%, 67 \%$ and $100 \%$ of inorganic chemistry fertilizers (NPK). Treatments supplemented with $200 \mathrm{~g}$ and $400 \mathrm{~g}$ of TD60 combined with $67 \%$ and $33 \%$ of recommended quantities of inorganic chemical fertilizers respectively recorded optimal maize yields $(13,213.25 \mathrm{Kg} / \mathrm{ha}$ and $13,059.00 \mathrm{Kg} / \mathrm{ha}$ respectively) which is an increase of about $837 \%$ and $826 \%$ higher than the treatment with no chimato compost TD60 and no fertilizer input (pure control treatment) and $248 \%$ and $430 \%$ higher than the treatments supplemented with no chimato compost TD60 but supplemented with $33 \%$ and $67 \%$ of inorganic chemistry fertilizers (NPK) respectively (Table 3). The results further shows that maize yield in treatment supplemented with $400 \mathrm{~g}$ of Td60 combined with $33 \%, 67 \%$ and $100 \%$ of recommended quantities of inorganic chemical fertilizers increased by a margin of $807 \%, 809 \%$ and $805 \%$ higher than the no input control and were not significantly different from each other $(\mathrm{p}<0.001, \mathrm{a}=0.05$, Wilcoxon). The observation indicates significant improvements such that if adopted could benefit majority of the smallholder farmers in Malawi who fail to produce enough food for their households (Benson et al., 1997; Ganunga, 1998; Murugan \& Swarnam, 2013). 


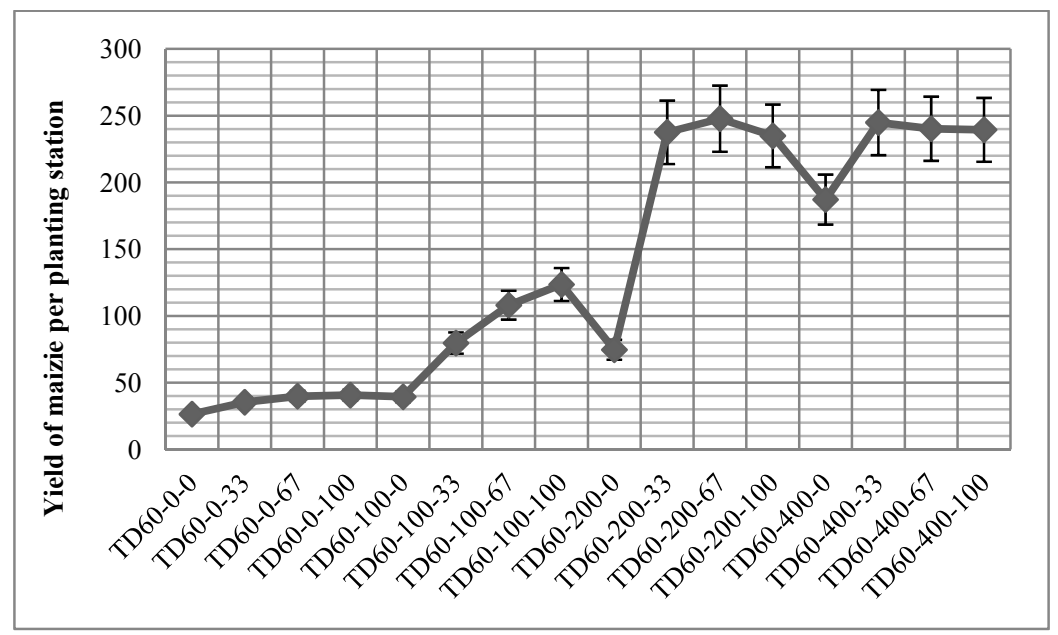

Figure 3. Yield of maize per planting station (TD60-0-0 stands for treatment supplemented with $0 \mathrm{~g}$ of TD60 combined with $0 \mathrm{~g}$ of inorganic chemistry of fertilizers; (TD60-0-33 stands for treatment supplemented with $0 \mathrm{~g}$ of TD60 combined with $33 \mathrm{~g}$ of inorganic chemistry of fertilizers; (TD60-100-33 stands for treatment supplemented with $100 \mathrm{~g}$ of TD60 combined with $33 \mathrm{~g}$ of inorganic chemistry of fertilizers; and so on)

As shown in Figure 3, largest maize yield per planting station was obtained in treatment TD60-200 and TD60-400 supplied by $67 \%$ and $33 \%$ of RICF respectively then by TD $60-200$ supplied by $33 \%$ and $100 \%$ of RICF followed by TD60-400 supplied by $67 \%$ and $100 \%$ of recommended quantities of inorganic chemical fertilizers. Least yield was obtained in control treatment TD60-0 treated with no chemical fertilizers, followed by TD60-0 treated by $33 \%$ and $67 \%$ of RICF then TD60-100 and TD60- 0 treated by $0 \%$ and $100 \%$ RICF respectively. However, yield of TD60-100 and TD60-0 treated by $0 \%$ and $100 \%$ of recommended quantities of inorganic chemical fertilizers were not significant different from each other. Thus full dosage of recommended fertilizers produced equivalent yield with poor soils treated with chemical fertilizers only. The observation could be attributed to fast leaching of nutrients in control experiments since compost act like a sponge that release nutrients gradually (Murugan \& Swarnam, 2013, Jama et al., 2000)

\section{Conclusion and Recommendations}

The study results have also shown that supplementing with $200 \mathrm{~g}$ and $400 \mathrm{~g}$ chimato compost TD60 per planting station made using at least $60 \%$ of $T$. diversifolia would supply crops with nitrogen equivalent to what recommended rates of application of Urea or NPK (23-20-0-4S) would supply. Maize crop growth parameters (cob length, cob circumference, leaf length and plant height) supplemented with compost treatment TD60 only and a combination of varied combination of TD60 and inorganic chemical fertilizers were linearly related to quantities of chimato compost strongly related to combinatorial quantities of compost TD60 and inorganic chemical fertilizers. It has also been shown that $200 \mathrm{~g}$ of TD60 induce optimum growth in cob circumference, cob length, plant height and leaf length where as $400 \mathrm{~g}$ induced growth of cob length, cob circumference, plant height and leaf length not significantly different from those of $200 \mathrm{~g}$ of TD60. The results have also a combination of $200 \mathrm{~g}$ and $400 \mathrm{~g}$ of TD60 with $33 \%$ and $67 \%$ of inorganic chemical fertilizers produced optimal plant growth and maize yield respectively. Yield increased by over $400 \%$ which is a significant contribution in food security while inorganic chemical fertilizers requirements reduced by $67 \%$ and $33 \%$ respectively. the results further shows that chimato compost produced by blending $60 \% \mathrm{~T}$. diversifolia has potential of increasing maize yield in fields with declining soil fertility. However, there is need to investigate the extent to which TD60 can suppress or control emergence of witch-weed prone.

\section{References}

Babajide, P. A., Olabode, O. S., Akambi, W. B., Olatunji, O. O., \& Ewetola, E. A. (2008). Influence of composted Tithonia-biomass chemical and N-mineral fertilizer on soil physic-chemical properties and performance of tomato (Lycopericon lycopericum). Research Journal of Agronomy, 2(4), 101-106.

Benson, T. D. (1997). Annotated bibliography of the work on area-specific fertilizer recommendations for maize in Malawi. Maize Commodity Team Annual Report for the year 1995/96. Chitedze Agricultural Research Station, Malawi. 
Benson, T. D., Kumwenda, J. D. T., \& Gilbert, R. A. (1997). The 1995/96 Maize Fertilizer Verification Trials-Malawi. Hybrid maize yields by treatment. Ministry of Agriculture and Irrigation, Chitedze Research Station, Lilongwe, Malawi.

Biddlestone, A. J., \& Gray, K. R. (1987). Production of Organic Fertilizers by Composting, In D. J. Moriarty, \& R. S. V. Pullin (Eds.), Detritus and Microbial Ecology in aquaculture (pp.151-180). ICLARM Conference proceeding, International Centre for living aquatic resources management, Philippines.

Chang, C. H., Chen, I. C., \& Yang, S. S. (2009). Methane and Carbon Dioxide Emissions from Different Composting Periods. Terr. Atmos. Ocean. Sci., 20(3), 511-520.

Darlington, W. (2010). Compost- A guide for evaluating and using compost material as Soil amendments. Soil and Plant Laboratory, Inc., 714(282), 8777-8788.

Gachengo, C. N., Palm, C. A., Jama, B., \& Othieno, C. (1999). Tithonia and Senna green manures and inorganic fertilizers as phosphorus sources for maize in Western Kenya. Agro-forestry Systems, 44(1), 21- 36.

Ganunga, R., Yerokun, O., \& Kumwenda, J. D. T. (1998). Tithonia diversifolia: an organic source of nitrogen and phosphorus for maize in Malawi. In S. R. Waddington (Eds.), Soil fertility research for maize-based farming systems in Malawi and Zimbabwe (pp. 547-567). Retrieved July 19, 2009, from http://books.google.com/books/Ganunga

Jama, B., Palm, C. A., Buresh, R. J., Niang, A., Gachengo, C., Nziguheba, G., \& Amadalo, B. (2000). Tithonia diversifolia as a green manure for soil improvement in Western Kenya: A Review. Agro-forestry Systems, 49(1), 201-221. http://dx.doi.org/10.1023/A:1006339025728

Mlangeni, A., \& Chiotha, S. S. (2013). Potential of T. diversifolia chimato composts in enhancing soil carbon sequestration. Environment and Natural Resources Research, 3(4), 58-67. http://dx.doi.org/10.5539/enrr.v3n4p58

Mlangeni, A., Sajidu, S., \& Chiotha, S. (2013). Total Kjeldahl-N, Nitrate-N, Carbon/Nitrogen Ratio and pH Improvements in Chimato Composts Using T. diversifolia. Journal of Agricultural Science, 5(10), 1. http://dx.doi.org/10.5539/jas.v5n10p1

Murugan, A. V., \& Swarnam, T. P. (2013). Nitrogen release pattern from organic manures applied to an acid soil. Journal of Agricultural Science, 5(6), 174. http://dx.doi.org/10.5539/jas.v5n6p174

Onwueme, I. C., \& Sinha, T. D. (1991). Field crop production in Tropical Africa: Principles and practice. Ede, Netherlands: Technical Centre for Agricultural and Rural Co-operation (CTA).

Stoddard, E. (2005). Deforestation and erosion starving Malawi. Reuters. Retrieved February 10, 2009, from http://news.mongabay.com/2005/1013-reuters.html

Swift, M. J., Heal, O. W., \& Anderson, J. M. (1979). Decomposition in terrestrial Ecosystem. Oxford: Blackwell Scientific Publication.

Tchale, H. (2006). Agricultural policy, soil fertility management, and productivity in the maize-based smallholder farming system in Malawi. Development, Economics and Policy, 53, 33-36.

UNIU (University of Illinois at Urbana-Champaign). (2014). Agronomy facts: Nitrogen and Soil Organic Matter. Soil Fertility and Testing. College of Agricultural, Consumer and Environmental Sciences. Retrieved March 20, 2014, from http://web.aces.uiuc.edu/vista/pdf_pubs/sf-11.pdf

\section{Copyrights}

Copyright for this article is retained by the author(s), with first publication rights granted to the journal.

This is an open-access article distributed under the terms and conditions of the Creative Commons Attribution license (http://creativecommons.org/licenses/by/3.0/). 